\title{
Insects are flying shrimps, myriapods are arthropod snakes - towards a new synthesis
}

\section{D.E. Shcherbakov}

\begin{abstract}
Borissiak Paleontological Institute RAS, Profsoyuznaya Str. 123, Moscow 117647, Russia. E-mail:dshh@narod.ru
\end{abstract}

\begin{abstract}
The first Atelocerata were machilid-like insects descended from Palaeocaridacea (Malacostraca Syncarida) via neoteny, homeosis and gamoheterotopy. In these littoral hoppers, the five posterior segments of the malacostracan thorax were repatterned after abdominal ones to maintain the caridoid escape reaction at uncompensated gravity out of water. Their modified gonopods were shifted caudally and transferred from males to females to form an ovipositor. The vigorously flexing abdomen turned useless in cryptic habitats and was homeotically repatterned after the thorax in myriapods, which evolved as litter creepers from bristletail ancestors via entognathous hexapods.

How to cite this article: Shcherbakov D.E. 2017. Insects are flying shrimps, myriapods are arthropod snakes — towards a new synthesis // Invert. Zool. Vol.14. No.2. P.197-204. doi: 10.15298/invertzool.14.2.15
\end{abstract}

KEY WORDS: Malacostraca, Insecta, Archaeognatha, Myriapoda, homeosis, thorax, abdomen.

\section{Насекомые как летучие креветки, многоножки как членистоногие змеи - к новому синтезу}

\section{Д.Е. Щербаков}

Палеонтологический институт им. А.А. Борисяка РАН, ул. Профсоюзная 123, Москва 117647, Россия. E-mail: dshh@narod.ru

PЕЗЮМЕ: Первые Atelocerata, насекомые напоминавшие махилид, произошли от Palaeocaridacea (Malacostraca Syncarida) путем неотении, гомеозиса и гамогетеротопии. У этих прибрежных прыгунов пять последних сегментов рачьей груди были уподоблены брюшным, чтобы сохранить каридоидную реакцию бегства при некомпенсированной гравитации вне воды. Модифицированные гоноподы самцов были сдвинуты к хвосту и перенесены на самок, превратившись в яйцеклад. Скрытоживущим формам не нужно брюшко, способное резко подгибаться, и оно было гомеотически уподоблено грудному отделу у многоножек, приспособившихся к ползанию в подстилке и произошедших от махилид через энтогнатных гексапод.

Как цитировать эту статью: Shcherbakov D.E. 2017. Insects are flying shrimps, myriapods are arthropod snakes — towards a new synthesis // Invert. Zool. Vol.14. No.2. P.197-204. doi: 10.15298/invertzool.14.2.15

КЛЮЧЕВЫЕ СЛОВА: Malacostraca, Insecta, Archaeognatha, Myriapoda, гомеозис, грудь, брюшко. 


\section{Shrimps jump ashore}

There are two alternative theories of insect origin. The myriapod theory goes back to Brauer (1869): insects descended from myriapods, and the first insects were similar to Campodea. The crustacean theory was elaborated by Hansen (1893): insects evolved from higher crustaceans (Malacostraca), and the first insects resembled Machilis.

The crustacean theory, based on comparative morphology and embryology (Crampton, 1918, 1938; Hansen, 1925, 1930; Sharov, 1966), was substantiated by deep similarities in the structure of visual system (Nilsson, Osorio, 1998) and brain (Strausfeld, 2009), neurogenesis (Whitington, Bacon, 1998), and expression patterns of segmentation genes (Patel, 1994). Molecular phylogenetics also supports the crustacean-insect relationships. In at least some molecular trees, the sister group of insects is the Malacostraca (Garcia-Machado et al., 1999; Wilson et al., 2000).

As Crampton (1922) has put it, "Furthermore, there is no possibility of being deceived by "convergent" development in this instance, since the remarkable resemblance, both anatomical and embryological, present in so wide a series of structures from such different parts of the body, and extending even to the minutest details, in [crustaceans and insects], can be explained only as the result of consanguinity. Since convergent development is supposedly the result of the effects of similar environmental conditions, it is difficult to believe that the environment of a marine crustacean (or even a littoral one) can have enough in common with the environment of a terrestrial insect (in some cases mountain-dwelling ones) to produce the astoundingly close similarity one finds in the minutest structural details in the two groups of arthropods!"

The crustaceans most similar to insects are the Eumalacostraca (known since the Devonian), particularly the Syncarida(Tillyard, 1930), and, of these latter, the Palaeocaridacea, known from the Carboniferous and Early Permian (Schram, 1984, 1986; Perrier et al., 2006), and possibly the Devonian (Devonocaris; Wells, 1957; Brooks, 1962). Many features of Palaeocaridacea were inherited by the Archaeognatha and other insects: the trunk of 14 segments plus the telson; the carapace undeveloped; the $1 \mathrm{st}$ thoracomere free; the 1 st and sometimes also 23rd thoracopods specialized as maxillipeds in contrast to the 4-8th ones; thoracopods with a short exopod; pleopods simpler and smaller than thoracopods, with the endopod sometimes reduced and in two (1-2nd) pairs produced to form the male organ; uropods (their endopods homologous to insect cerci - Crampton, 1921) and the telson sometimes spikelike; male gonopores situated two segments more posterior than in females; and the embryonic dorsal organ of the same structure and position (Sharov, 1966).

The insects most closely resembling malacostracans are jumping bristletails (Archaeognatha, since the Triassic - Montagna et al., 2017) and related Monura (Carboniferous-Triassic, possibly the Devonian - Labandeira et al., 1988). Jumping bristletails represent the ancestral, crustaceoid type better than any other living hexapod (Crampton, 1938). They retain numerous malacostracan features: tagmosis with rather smooth transitions between the head, thorax and abdomen; the tail fan (cerci, i.e. limbs of the 11th abdominal segment, and the paracercus); a full set of abdominal limbs (freely projecting, styli-bearing coxites participating in locomotion); exopods (coxal and abdominal styli); abdominal endopods (eversible vesicles); leg bases with coxo-trochanteral joints close to the midline; paranotal lobes concealing limb bases; compound eyes structurally similar to those of Crustacea; the naupliar eye transformed into ocelli; huge 1st antennae with an annulate flagellum; the supramandibular suture; limblike maxillary palps; well-developed paragnaths (hypopharynx); and the 2nd maxillae (fused basally to form the labium) similar to the $1 \mathrm{st}$ maxillae. The rolling machilid mandibles with a separate incisor, elongated mola and posterodorsal adductor muscle are sub-ectognathous, with their posterior articulation hidden under the paranotal fold of the mandibular segment 
(Manton, 1964) and functionally dicondylic, with incipient anterior articulation, i.e. like in Zygentoma, so there is no reason to abandon the concept of the Thysanura s.l. (Kluge, 1996).

Insects are neotenic in retaining such embryonic syncarid characters as sessile eyes and uniramous 1st antennae and uropods (=cerci). These transformations correlate with terrestrialization, as well as the loss of a swimming larva (nauplius) with suppression of its natatory limbs (2nd antennae and mandibular telopodites = palps), and acquisition of tracheae (Boudreaux, 1979). Probable rudiments of the 2 nd antenna are found in modern machilids, campodeids and grasshoppers (Crampton, 1932).

Because the segment number is irrelevant for determining homology of tagmata (Minelli, Peruffo, 1991), three principal tagmata - head, thorax and abdomen - can be traced throughout the Arthropoda. The sets of homeotic genes controlling this tagmosis are basically similar in all arthropods (Carroll, 1995). Each segment of the arthropod body is capable of producing a fully developed basically biramous limb or, in insects, both leg and wing, the latter being homologous to the distal epipodite of the crustacean limb (Averof, Cohen, 1997). Therefore, a ground plan segment is thoracic, whereas in the limbless, e.g. abdominal, segments limb development is suppressed (Carroll et al., 1995).

The arthropod abdomen likely appeared as an integral locomotory organ, initially short (a muscular stalk bearing a tail fin or styliform telson), and became enlarged in Crustacea with the development of the caridoid escape reaction, i.e. an emergency tail-flip or jump (Shcherbakov, 1996). This reaction, shared by Malacostraca, Archaeognatha and nymphal Ephemeroptera, is served by specialized muscles in the abdomen (Matsuda, 1957; Hessler, 1983; E.L. Smith in Kukalová-Peck, 1987).

A larger volume of abdominal muscles is needed for jumping at uncompensated gravity in air than for tail-flipping in water (importance of the gravitation factor for insect origins was stressed by Mamayev, 1977). Tillyard (1930), though a proponent of the myriapod theory, admitted: "All that is necessary, then, for a
[Syncarid] to become a Machilid, as far as segmentation is concerned, is for the last five thoracic segments to change their function and become abdominal, with consequent reduction of their appendages to vestiges!" I suggest that five posterior segments of the malacostracan thorax were homeotically repatterned after abdominal ones to maintain the escape reaction in open terrestrial habitats, so the insect thorax corresponds to the maxillipedal part of the malacostracan thorax. It was five segments that underwent transformation because hexapody is optimal for a faster gait. Furthermore, the set of modified gonopods (and the expression domain of the underlying homeotic gene Abdominal-B; Averof, Akam, 1995) was shifted caudally and transferred from males to females to form an ovipositor, allowing insertion of eggs into substrate crevices, which is adaptive in open-living terrestrial forms (Fig. 1).

Such transformation of a syncarid into a machilid took place through heterochrony (neoteny), heterotopy (homeosis) and gamoheterotopy, i.e. shift of characters from one sex to another (Meyen, 1988). Unlike heterochrony, heterotopies produce no parallelisms between ontogeny and phylogeny: instead of resembling an ancestor at a different developmental stage, a novelty created by heterotopy will differ from any stage of the ancestral ontogeny (Zelditch, Fink, 1996).

Insect ancestors were thought to come ashore through the splash zone leaping from waves like talitrid amphipods (Tshernyshev, 1997). However, among five major routes of arthropod terrestrialization (Labandeira, Beall, 1990) the freshwater route, used by various decapods, agrees with the syncarid-machilid ancestry of insects better than littoral routes. Living syncarids occur in fresh water and one of them, Anaspides, is occasionally found on land naturally, exploring areas adjacent to pools (Swain, Reid, 1983). Paleozoic syncarids (Palaeocaridacea) apparently preferred brackish or fresh water (found in deltaic, swampy and lagoonal facies; Schram, 1986; Briggs, Clarkson, 1989); some genera (Acanthotelson, Pleurocaris) possess styliform tailfan lobes suitable for leaping in air 

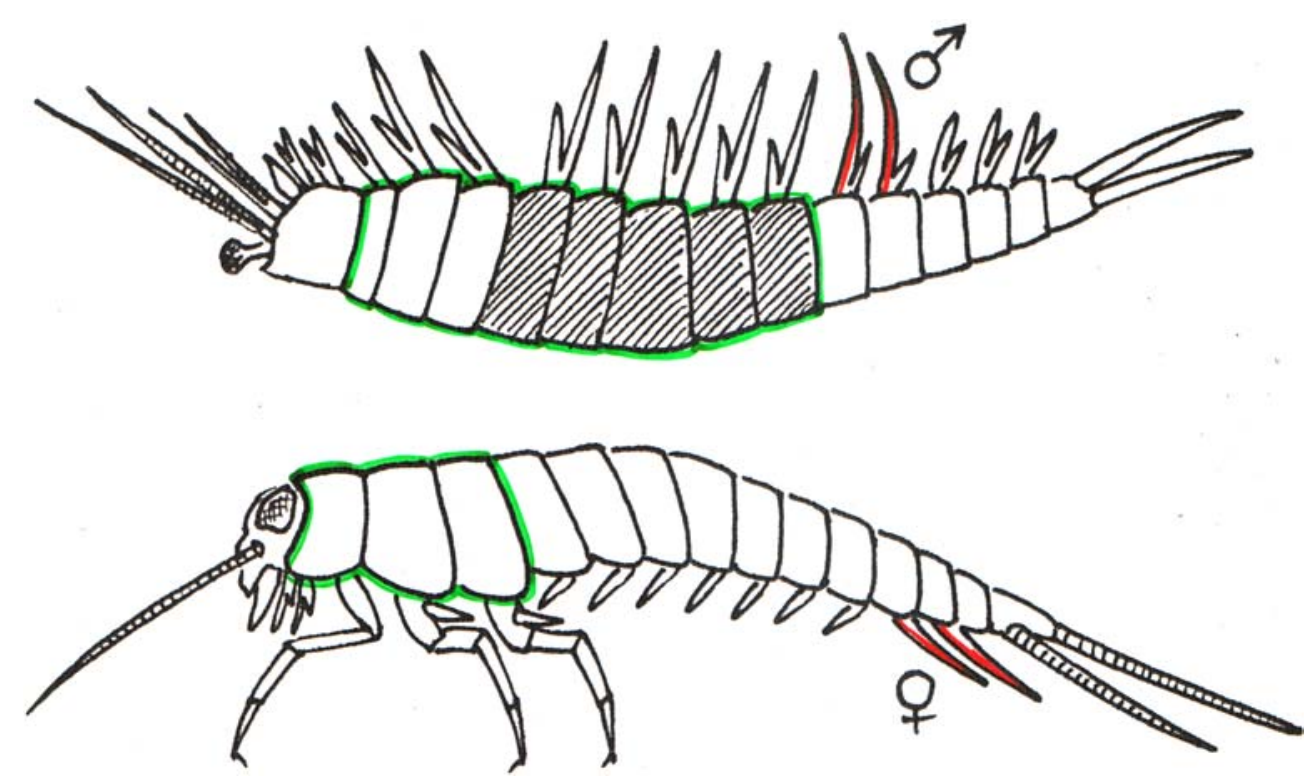

Fig. 1. Body plans of palaeocaridids and machilids compared. Shaded, malacostracan posterior thorax repatterned after abdomen in insects.

Рис. 1. Сравнение планов строения палеокаридид и махилид. Заштрихована задняя часть груди высших раков, вошедшая в состав брюшка насекомых.

rather than tail-flipping in water. The Archaeognatha sometimes inhabit seashore rocks and are capable of gliding on water and jumping from it, but apparently have never been associated with continental waters. However, monurans are thought to have been living near water, on emergent plants and floating mats and escaping from arachnid predators by powerful leaps (Kukalova-Peck, 1987). This assumption is documented by Carboniferous monuran traces, some of them left by insects probing the sediment with palps while afloat on a millimeterdeep water layer (Mangano et al., 1997). Suppression of cerci in Monura, a neotenic trait, may have been associated with habitat preference. Modern machilids are able to jump in any direction, essentially at random (Evans, 1975). Apparently, a random sequence of jumps is better suited to escape from predators than from waves.

The impressions of the ovipositor in some of the above-mentioned fossil traces of Monura (Mangano et al., 1997) suggest that their ovipositor was shorter and stouter than in the present-day Thysanura s.l., and apparently better suited for penetrating plant tissues. This agrees with the idea that plant stems and, especially, sporangia were the safest place to hide insect eggs in turbulent proluvial waters (Omodeo et al., 1980). If monurans indeed inserted their eggs into plants, the association of insects with plant reproductive organs had already formed at the apterygote stage.

The mandible of Archaeognatha represents the type ancestral for both ectognathous (biting, fully dicondylic) and entognathous (monocondylic or suspended, stylet-like) mandibles (Bitsch, 1994). Archaeognathan mouthparts, forming a functionally closed oral cone, are adapted for scraping-and-sucking (Manton, 1964); the inner space of the mouth cone forms a preoral cavity considered a prerequisite for terrestrial life (Størmer, 1976). Such mouthparts are preadapted for transformation into a suctorial beak, so it is not surprising to find so many winged insects with beaks and proboscides already in the Carboniferous. 


\section{Myriapods lurk in the dark}

The evo-devo studies support the old idea of a secondary nature of the myriapod body plan (Börner, 1903). The complexity of the homeotic gene system makes the body heteronomy much more difficult to create de novo than to modify one previously evolved by shifting boundaries between tagmata or revert it to homonomy by turning off underlying genes (e.g. derepressing limb development in abdominal segments). Parallel development in insects and crustaceans of the same homeotic gene mechanism controlling tagmosis appears virtually impossible. Instead, partial turning it off in myriapods and myriapod-like crustaceans (Remipedia) could have made their trunks secondarily homonomous and thorax-like (Averof, Akam, 1993; Akam et al., 1994). The homonomous trunk in these forms makes a sharp contrast to the highly specialized head tagma. Likewise, in snakes, a homeotic change - expansion of expression domains of the genes encoding thoracic identity into both abdominal and cervical regions - resulted in the trunk axial skeleton becoming similar to the thorax and the limbs, absent in the ground-plan vertebrate metamere, lost (Cohn, Tickle, 1999).

In arthropods, a loss of trunk heteronomy becomes possible when the vigorously flexing abdomen turns useless, e.g. in cryptic habitats. The loss of trunk tagmosis and reduction of eyes in myriapods may be adaptations to a burrowing lifestyle (Hennig, 1981; Osorio et al., 1995). However, in most myriapods the trunk is not perfectly homonomous - usually the first three trunk segments (= insect thorax), and often also the 4-8th ones (= non-maxillipedal malacostracan thorax, converted into anterior abdomen in insects) are subtagmata still distinct from the following segments (= malacostracan abdomen; Fig. 2).

Entognathous hexapods are "pre-myriapods" transitional from thysanurans to myriapods. Entognatha and Myriapoda, most of which are soil dwellers, have many traits of open-living bristletails and their malacostracan ancestors variously modified or lost: the head tagma contrasted to the homonomous trunk; paranota re- duced; leg bases widely separated; cerci lost; eyes reduced; ocelli suppressed; the 2nd maxillae leg-like or lost; palps reduced; and sperm immotile. Mandibles turned entognathous in Entognatha, Chilopoda and Pauropoda; the condition in Symphyla and Diplopoda is also far from true ectognathy, because their mandibles remain suspended anteriorly on movable levers (fulturae). Secondarily subdivided myriapod mandibles with the anterodorsal adductor muscle became similar to the maxillae, probably through homeosis. In Myocerata (= Entognatha + Myriapoda), the 1st antennae with true, musculature-containing flagellar segments were probably homeotically repatterned after palps or legs. Neoteny explains various reductions in myocerates as well as similarity of enlarged limb rudiments on the 1 st abdominal segment in Protura, Collembola, and some Diplura to embryonic pleuropodia of Thysanura.

The Diplura are related to lepismatids, and the Collembola descended from ancestors close to the Diplura (Dallai, 1980). The Ellipura (= Collembola + Protura) were considered as a possible sister-group of the Myriapoda (Zrzavy, Štys, 1994). The structure of their abdomen, with subterminal gonopore, is by no means primitive, even in Protura, which anamorphically develop 3 subterminal segments (one more than in insects), possibly mere subdivisions of the true 8th segment. The myriapods most similar to hexapods, namely to Diplura, are the Symphyla (Tillyard, 1930). In both Entognatha and Myriapoda, the proto- and deutocerebra are strongly tilted backwards, lying over the stomodaeum, and postantennal organs are developed. Embryological similarities of Diplura and Collembola with Myriapoda are impressive (Zachvatkin, 1975): the ovary not subdivided into ovarioles; plagiaxony; a ventrally bent germ band; amnion and serosa lacking; the extraembryonic blastoderm transformed into the provisional body wall and embryonic dorsal organ (of the same type in Diplura, Collembola and Symphyla).

Myriapods evolved from hexapods, and the six-legged larvae of Diplopoda and Pauropoda recapitulate the ancestral state. In hexapods, the 


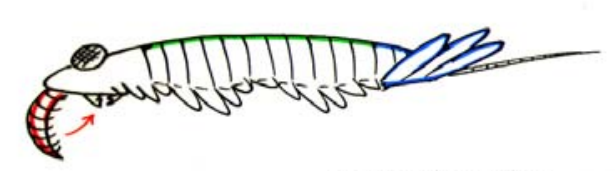

Anomalocarida

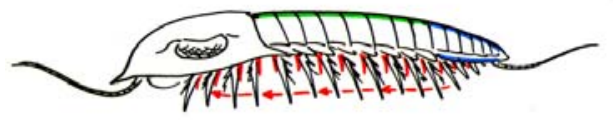

Trilobita

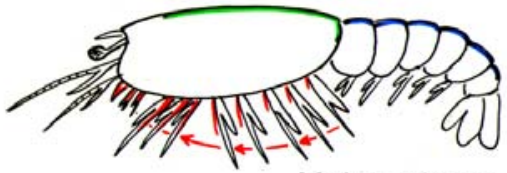

Malacostraca

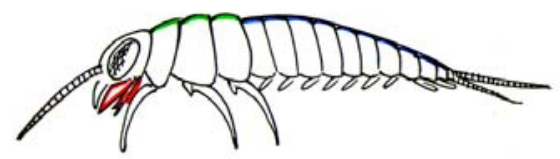

Thysanura

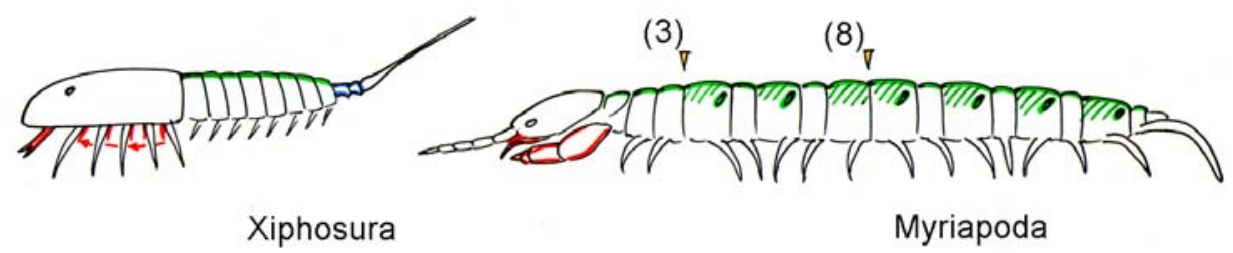

Fig. 2. Body plans of different arthropod groups. Arrows, food transport.

Рис. 2. Планы строения различных групп членистоногих. Стрелками показано направление транспорта пищи.

loss of trunk heteronomy was probably an easier way to restore multiple limb-bearing segments, useful in cryptic habitats, than repatterning of abdominal segments one by one. This homeotic transformation is modeled by a total deletion of the Homeotic complex in Drosophila, resulting in repatterning of the entire trunk and, moreover, both maxillary segments after the prothoracic one (Raff, Kaufmann, 1991). A reversal of the 2nd maxillae to a leg-like condition in Chilopoda or their reduction to eversible vesicles (characteristic of trunk segments) in Pauropoda and complete suppression in Diplopoda seem to be mere by-products of the genetic mechanism governing myriapodization.

Contrary to the common opinion, the Remipedia and Myriapoda are highly modified rather than primitive subtaxa of Crustacea and Atelocerata, respectively. Likewise, their legless tetrapod analogs, Serpentes and Amphisbaenia in the Reptilia and Gymnophiona and Aistopoda in the Amphibia, are highly derived. Like myriapods, snakes and other limbless tetrapods secondarily acquired a superficially homonomous trunk (for creeping or burrowing locomotion in litter or soil) containing more numerous metameres (vertebrae), and have the head more specialized than in primitive heteronomous forms. Like myriapods, snakes are terrestrial in origin, and there is no reason to assume that the first of them were aquatic (Hsiang et al., 2015). Both a lancelet and a snake are legless, but the latter's body plan is highly derived, in particular because its head tagma includes variously modified metameres (branchial arches), sometimes bearing poison teeth, and sharply separated from the trunk by a neck region. Likewise, both a trilobite and a millipede (or centipede) are multilegged, but the latter is in no way primitive, with its head region containing a limbless collum and variously specialized limbs (up to becoming poison fangs), which, like the trunk limbs, are far from the biramous trilobite condition. Paired limbs are absent from the ground-plan vertebrate metamere but present in the ground-plan (thoracic) arthropod segment, so that both snake leglessness and myriapod total legness are partial reversals to the ground plan. Deriving thys- 
anurans from myriapods is no more logical than deriving lizards from snakes, the more so because the transformation series from trilobites via crustaceans to hexapods is nearly as smooth as that from fishes to reptiles.

By thinking beyond cladistics and by interpreting any phylogeny as a branching chain of now paraphyletic but once holophyletic taxa (Rasnitsyn, 1996; Hörandl, Stuessy, 2010), we can see no dilemma in the crustacean-insectmyriapod relationships. I hypothesize that myriapods evolved as litter creepers with the trunk heteronomy suppressed but still traceable from bristletail-like hoppers via entognathous hexapods (Shcherbakov, 1999).

\section{Acknowledgements}

I am grateful to Ed Jarzembowski (London), Alex Rasnitsyn, Roman Rakitov, Andrey Zhuravlev (Moscow) and other colleagues for suggestions and comments on the manuscript. The ongoing study is supported by the RFBR project 16-04-01498.

\section{References}

Akam M., Averof M., Castelli-Gair J., Dawes R., Falciani F., Ferrier D. 1994. The evolving role of Hox genes in arthropods // Development. 1994 Suppl. P.209-215.

Averof M., Akam M. 1993. HOM/Hox genes of Artemia: implications for the origin of insect and crustacean body plans // Curr. Biol. Vol.3. P.73-78.

Averof M., Akam M. 1995. Hox genes and the diversification of insect and crustacean body plans // Nature. Vol.376. P.420-423.

Averof M., Cohen S.M. 1997. Evolutionary origin of insect wings from ancestral gills // Nature Vol. 385. P.627-630.

Bitsch J. 1994. The morphological groundplan of Hexapoda: critical review of recent concepts // Ann. Soc. Entomol. Fr. (N.S.). Vol.30. No.1. P.103-129.

Börner C. 1903. Über die Beingliederung der Arthropoden (3. Mitteilung., die Cheliceraten, Pantopoden und Crustaceen betreffend) // Sitzber. Ges. naturf. Frd. Berlin. 1903. S.292-341.

Boudreaux H.B. 1979. Arthropod Phylogeny with Special Reference to Insects. N.Y.: Wiley. VIII + 320 p.

Brauer F. 1869. Betrachtung über die Verwandlung der Insecten im Sinne der Descendenz-Theorie // Verh. Zool.-Bot. Ges. Wien. Bd.19. S.299-318.

Briggs D.E.G., Clarkson E.N.K. 1989. Environmental controls on the taphonomy and distribution of Carboniferous malacostracan crustaceans // Trans. R. Soc. Edinb. Earth Sci. Vol.80. P.293-301.
Brooks H.K. 1962. Devonian Eumalacostraca // Ark. Zool. Vol.15. P.307-315.

Carroll S.B. 1995. Homeotic genes and the evolution of arthropods and chordates // Nature. Vol.376. P.479485.

Carroll S.B., Weatherbee S.D., Langeland J.A. 1995. Homeotic genes and the regulation and evolution of insect wing number // Nature. Vol.375. P.58-61.

Cohn M.J., Tickle C. 1999. Developmental basis of limblessness and axial patterning in snakes // Nature. Vol.399. P.474-479.

Crampton G.C. 1918. The probable ancestors of insects and myriopods // Can. Entomol. Vol.50. P.285-288.

Crampton G.C. 1921. A comparison of the terminal abdominal structures of insects and Crustacea // Entomol. News. Vol.32. P.257-264.

Crampton G.C. 1922. The derivation of certain types of head capsule in insects from crustacean prototypes // Proc. Entomol. Soc. Wash. 24. No.6. P.153-158.

Crampton G.C. 1932. The probable occurrence in the thysanuroid insect Machilis heteropus Silv. of a structure homologous with the second antenna // Entomol. News. Vol.43. P.57-59.

Crampton G.C. 1938. The interrelationships and lines of descent of living insects // Psyche. Vol.45. P.165-181.

Dallai R. 1979. An overview of atypical spermatozoa in insects // D.W. Fawcett, J.M. Bedford (eds.). The Spermatozoon. Baltimore: Urban \& Schwarzenberg. P.253-265.

Evans M.E.G. 1975. The jump of Petrobius (Thysanura, Machilidae) // J. Zool. Vol.176. P.49-65.

Garcia-Machado E., Pempera M., Dennebouy N., OlivaSuarez M., Mounolou J.C., Monnerot M. 1999. Mitochondrial genes collectively suggest the paraphyly of Crustacea with respect to Insecta // J. Mol. Evol. Vol.49. P.142-149.

Hansen H.J. 1893. A contribution to the morphology of the limbs and mouth-parts of crustaceans and insects // Ann. Mag. nat. Hist. Ser.6. Vol.12. P.417-434.

Hansen H.J. 1925. Studies on Arthropoda. II. On the comparative morphology of the appendages in the Arthropoda. A. Crustacea. Copenhagen: Gyldendalske Boghandel. P.1-176.

Hansen H.J. 1930. Studies on Arthropoda. III. On the comparative morphology of the appendages in the Arthropoda. B. Crustacea (supplement), Insecta, Myriopoda, and Arachnida. Copenhagen: Gyldendalske Boghandel. P.1-376.

Hennig W. 1981. Insect Phylogeny. Chichester: Wiley. XXII $+514 \mathrm{p}$.

Hessler R.R. 1983. A defense of the caridoid facies; wherein the early evolution of the Eumalacostraca is discussed // F.R. Schram (ed.). Crustacean Phylogeny. Rotterdam: Balkema. P.145-164.

Hörandl E., Stuessy T.F. 2010. Paraphyletic groups as natural units of biological classification // Taxon. Vol.59. P.1641-1653.

Hsiang A.Y., Field D.J., Webster T.H., Behlke A.D., Davis M.B., Racicot R.A., Gauthier J.A. 2015. The origin of snakes: revealing the ecology, behavior, and evolu- 
tionary history of early snakes using genomics, phenomics, and the fossil record // BMC Evol. Biol. Vol.15. No..87.

Kluge N.J. 1996. A new suborder of Thysanura for the Carboniferous insect originally described as larva of Bojophlebia, with comments on characters of the orders Thysanura and Ephemeroptera // Zoosyst. Ross. Vol.4 (for 1995). P.71-75.

Kukalová-Peck J. 1987. New Carboniferous Diplura, Monura, and Thysanura, the hexapod ground plan, and the role of thoracic side lobes in the origin of wings (Insecta) // Can. J. Zool. Vol.65. P.2327-2345.

Labandeira C.C., Beall B.S. 1990. Arthropod terrestriality // S.J. Culver (ed.). Short Courses in Paleontology 3, Arthropod Paleobiology. Paleontological Society. P.214-256.

Labandeira C.C., Beall B.S., Hueber F.M. 1988. Early insect diversification: evidence from a Lower Devonian bristletail from Quebec // Science. Vol.242. P.913-916.

Mamaev B.M. 1977. Gravitation hypothesis of the origin of insects // Entomol.Rev. Vol.54. P.13-17.

Mangano M.G., Buatois L.A., Maples C.G., Lanier W.P. 1997. Tonganoxichnus, a new insect trace from the Upper Carboniferous of eastern Kansas // Lethaia. Vol.30. P.113-125.

Manton S.M. 1964. Mandibular mechanisms and the evolution of arthropods // Phil. Trans. R. Soc. B. Vol.247. P.1-183.

Matsuda R. 1957. Comparative morphology of the abdomen of a machilid and a rhaphidiid // Trans. Am. Entomol. Soc. Vol.83. P.39-63.

Meyen S.V. 1988. Origin of the angiosperm gynoecium by gamoheterotopy // Bot. J. Linn. Soc. Vol.97. P.171178.

Minelli A., Peruffo B. 1991. Developmental pathways, homology and homonomy in metameric animals // J. Evol. Biol. Vol.4. P.429-445.

Montagna M., Haug J.T., Strada L., Haug C., Felber M., Tintori A. 2017. Central nervous system and muscular bundles preserved in a 240 million year old giant bristletail (Archaeognatha: Machilidae) // Sci. Rep. Vol.7. Art. no.46016.

Nilsson D.-E., Osorio D. 1998. Homology and parallelism in arthropod sensory processing // R.A. Fortey, R.H. Thomas (eds.). Arthropod Relationships, London: Chapman \& Hall. P.333-347.

Omodeo P., Minelli A., Baccetti B. 1980. On the phylogeny of pterygote insects // Boll. Zool. Vol.47 (suppl.). P.49-63.

Osorio D., Averof M., Bacon J.P. 1995. Arthropod evolution: great brains, beautiful bodies // Trends Ecol. Evol. Vol.10. P.449-454

Patel N.H. 1994. The evolution of arthropod segmentation: insights from comparisons of gene expression patterns // Development. 1994 Suppl. P.201-207.

Perrier V., Vannier J., Racheboeuf P.R., Charbonnier S., Chabard D., Sotty D. 2006. Syncarid crustaceans from the Montceau Lagerstätte (Upper Carboniferous; France) // Palaeontology. Vol.49. P.647-672.

Raff R.A., Kaufman T.C. 1991. Embryos, Genes, and Evolution: The Developmental-Genetic Basis of Evo- lutionary Change. Bloomington: Indiana Univ. Press. XXVII + $395 \mathrm{p}$.

Rasnitsyn A.P. 1996. Conceptual issues in phylogeny, taxonomy, and nomenclature // Contrib. Zool. Vol.66. P.3-41.

Schram F.R. 1984. Fossil Syncarida // Trans. San Diego Soc. Nat. Hist. Vol.20. P.189-246.

Schram F.R. 1986. Crustacea. New York - Oxford: Oxford Univ. Press. XIV + 606 p.

Sharov A.G. 1966. Basic Arthropodan Stock. Oxford: Pergamon Press. XII + 271 p.

Shcherbakov D.E. 1996. Paraphyly and homeotic transformations in arthropod evolution // International Symposium on the Relationships of Major Arthropod Groups. Programme and Abstracts. London: Natural History Museum. P.24.

Shcherbakov D.E. 1999. Controversies over the insect origin revisited // Proc. 1st Internat. Palaeoentomol. Conf. Moscow 1998. Bratislava: AMBA projects. P.141-148.

Størmer L. 1976. Arthropods from the Lower Devonian (Lower Emsian) of Alken an der Mosel, Germany. Part 5: Myriapoda and additional forms, with general remarks on fauna and problems regarding invasion of land by arthropods // Senck. leth. Vol.57. P.87-183.

Strausfeld N.J. 2009. Brain organization and the origin of insects: an assessment // Proc. R. Soc. B. Vol.276. P.1929-1937.

Swain R., Reid C.I. 1983. Observations on the life history and ecology of Anaspides tasmaniae // J. Crust. Biol. Vol.3. P.163-172.

Tillyard R.J. 1930. The evolution of the class Insecta // Pap. proc. R. Soc. Tasmania. P.1-89.

Tshernyshev V.B. 1997. [The origin of insects and their early evolution from the ecological point of view] // Zhurn. Obshch. Biol. Vol.58. No.3. P.5-16 [in Russian].

Wells J.W. 1957. An anaspid crustacean from the Middle Devonian of New York // J. Paleontol. Vol.31. P.983984.

Whitington P.M., Bacon J.P. 1998. The organization and development of the arthropod ventral nerve cord: insights into arthropod relationships // R.A. Fortey, R.H. Thomas (eds.). Arthropod Relationships. London: Chapman and Hall. P.349-367.

Wilson K., Cahill V., Ballment E., Benzie J. 2000. The complete sequence of the mitochondrial genome of the crustacean Penaeus monodon: are malacostracan crustaceans more closely related to insects than to branchiopods? // Mol. Biol. Evol. Vol.17. P.863-874.

Zachvatkin Y.A. 1975. [Embryology of insects]. Moscow: Vysshaya Shkola. 328 p. [in Russian, with English summary].

Zelditch M.L., Fink W.L. 1996. Heterochrony and heterotopy: stability and innovation in the evolution of form // Paleobiology. Vol.22. P.241-254.

Zrzavy J., Štys P. 1994. Origin of the crustacean schizoramous limb: A re-analysis of the duplosegmentation hypothesis // J. Evol. Biol. Vol.7. P.743-756.

Responsible editor E.N. Temereva 